\title{
Emmanuel Levinas: Metaphor without Metaphysics
}

Levinas's treatment of metaphor and figural language in his posthumously published notebooks and conference lectures clarifies its status and implications in his formal published writings. These Notes are exploratory. They show him thinking through language about thinking through language. One of his first premises is, indeed, that thought happens in language, a linguistic turn that goes back to Nietzsche. Derrida later develops as a sign theory the intrinsic role of signifiers in formulating meaning, not as "reference" to a signified idea prior to them, as mere vehicles to thought, but rather to other signifiers in an ongoing chain of signification. ${ }^{1}$ As Levinas writes: language does not just "communicat[e] a prefabricated thought” (Levinas 2012, 319). "The word does not evoke an object by a sign ... there is no signification that so to speak exists outside of all language" (Levinas 2009, 334) and of which language would merely be a "servile translation" (Levinas 2009, 375).

The structure of metaphor is both a basis for and has traditionally reflected the sign-theory of signified expressed through or represented by a signifier, as tenor to vehicle, or abstract to concrete, or figural to literal. ${ }^{2}$ As Derrida analyzed in "White Mythology," traditional metaphor reproduces ontological structures to which it is also foundational. ${ }^{3}$ As in traditional metaphor, so in traditional metaphysics, a signifier is taken to be a "vehicle" to a signified as "tenor," assuming them to share a pre-given common feature to justify the transfer. Levinas in his war notebooks likewise exposes and recasts metaphor in its ontological implications. Metaphor there is not a particular rhetorical

\footnotetext{
1 "Communication presupposes subjects (whose identity and presence are constituted before the signifying operation) and objects (signified concepts, a thought that the passage of communication will have neither to constitute nor by all rights transform)" (Derrida 1972, 23).

2 I. A. Richards introduced the terms vehicle and tenor, picked up by Ricoeur for example in The Rule of Metaphor (1987), where the terms of metaphor are assigned as concrete and abstract (Rule 298), vehicle and tenor (Rule 294), and particular and general (Rule 300). Metaphor of course is a large topic in philosophical as well as literary analysis.

3 Derrida, in "White Mythology," claims that the terms traditionally assigned to metaphor to reproduce classic ontological distinction between sensible and intelligible, visible and invisible, with metaphoric transferring from the first to the second (Derrida 1982, 225-226). Ricoeur, in The Rule of Metaphor, disputes Derrida's account, claiming that metaphor can be employed metaphysically but need not be (Ricoeur 1987, 336-348).
}

Ә Open Access. ( 2021 Shira Wolosky, published by De Gruyter. (c) BY This work is licensed under the Creative Commons Attribution 4.0 International License. 
figure, but a figure for all figures and ultimately for language itself. In language generally, there is no signified prior to signifiers, determining their meanings. There is no prior idea or object whose meaning is merely conveyed by language. Instead of language as signifiers corresponding or referring to prior signifieds, signification in Levinas unfolds through a procession of signifiers, each of which refers to each other in ongoing inter-relationships. Metaphor in the broad sense of figuration becomes not a mere subtrope as comparison, but the model of language altogether: "Far from an exceptional phenomenon of language, as a figure or style among others, metaphor coincides with the phenomenon of language itself or of signification" (Levinas 2009, 337). All language is, from the outset, figural. Each signifier is a figure for each other, with no signified outside or beyond the unfolding of signification.

The traditional terms for metaphor thereby dissolve. There is no "literal" against "figural" meaning, whose usages in fact are confusing and inconsistent. For, in the history of exegesis where the terms originate, "literal" points to a historical signifier for a prior and truer spiritual meaning, as both Nietzsche and Derrida expose. ${ }^{4}$ In ordinary usage, however, "literal" indicates what is actual, often physical, with "figural" some further sense granted to it. Levinas's recasting of the terms clarifies and situates the meaning of a signifier in the signchains of their inter-relationality, which can take place on a variety of planes of order and hence a variety of senses. Signs mean in ways that Wittgenstein calls language games. There is no pre-given "signified" outside of signifying chains or networks of meaning. As signifiers signifying signifiers, each term of language is then a "figure" or signifier for another. The sense of any word emerges within the inter-relationality of signifiers in the unfolding signification in which each appears. Each of these signifying networks offers one or more levels or configurations of meaning.

Levinas here accords with Nietzschean language theory, as well as many twentieth-century thinkers writing after Nietzsche. When Nietzsche famously says in "Truth and Lying in an Extra-Moral Sense": "What then is truth? a mobile army of metaphors, metonyms, and anthropomorphisms, in short, a sum of human relations," his claim is that language, rather than signifying metaphysical truth, is relational to human meaning, "a sum of human relations"

\footnotetext{
4 Nietzsche, in The Dawn, lambasts biblical typology's absorption and unification of all "literal" images of the Old Testament into the "figural" meaning of the New: "Wherever any piece of wood, a switch, a ladder, a twig, a tree, a willow, or a staff is mentioned, this was supposed to indicate a prophecy of the wood of the cross" (Nietzsche 1968, \# 84). Derrida, in Of Grammatology, exposes the "literal" as itself a "figure" (Derrida 1974, 15). See also Wolosky, "Religion and Literature" (2018).
} 
(Nietzsche 1989, 250). His lecture notes on “Ancient Rhetoric" declares all "words" to be "tropes ... . with respect to their meanings" "Tropes" are the "proper nature," the "proper meaning” of words (Nietzsche 1989, 23-25). In Philosophy in the Tragic Age of the Greeks he similarly writes: "Words are but symbols for the relations of things to one another and to us" (Nietzsche 1962, 83). Nietzsche is here critiquing traditional claims that language is an "adequate expression" of a pregiven truth, as he puts it in "Truth and Lying” (Nietzsche 1989, 248). ${ }^{5}$ But he is also offering a positive claim of language, redefining the very meaning of meaning. Rather than deriving in "truth" in any metaphysical sense, Nietzsche is pointing towards the generation of linguistic meaning in human terms, as hermeneutic, interpretive action.

Levinas, like Nietzsche, Merleau-Ponty, and other post-Nietzschean philosophers, challenges not only traditional theories of metaphor and language, but also the ontological structures upon which they are based and which they reflect. Traditional theory structures metaphor as reflecting an ontological hierarchy of concrete/abstract, literal/figural, signifier/signified. This reproduces the Platonist ontology of an intelligible, unchanging eternal ideal realm of true Being which temporal material realm of Becoming reflects as a lesser and less true reality. Levinas rejects this two-world system. This Nietzschean overcoming of metaphysics resituates language in Levinas away from the two-world system of intelligible/material, unchanging eternal/temporal historical worlds. In Levinas there are no two worlds, no higher ontology beyond time governing a lower, thinner ontology as shadowy copy whose reality, substance, meaning, and truth derive in the higher world. Meaning, for Levinas, is situated within the phenomenal world of time, matter, history, as the interrelationship among its particulars. There is "rapprochement of meaning and another meaning," but not "correspondence," which "no longer has anything in common with the system in which meaning laterally posits itself” (Levinas 2012, 321). Meaning is horizontal, "lateral" and not vertical, which is to say not invoking or referring to essences or universals shared or common among particulars.

What Levinas here outlines is a switch from a referential to a relational theory of language, as Nietzsche did, as Wittgenstein does, and as Derrida later formulates in terms of signifying chains, a term Levinas also introduces. "Language is not a group of names designating essences of things acts and relations" but instead it "already exceeds "this is" (en tant que) (as, like, as if)

5 Maudemarie Clark offers a detailed discussion of Nietzsche and correspondence theory in Nietzsche on Truth and Philosophy, disputing that Nietzsche rejects correspondence theory as the majority of commentators claim, but also redefining correspondence theory in more pragmatist directions as correspondence to "common sense" (Clark 1990, 34-38, 61). 
another thing" (Levinas 2009, 337). As Levinas continues, language theory here is deeply hermeneutical. The sign-chains that situate meaning act as interpretive frameworks in which each signifies, what Levinas describes as a Heideggerean "world:" "The fact that every signification signifies in a context, or as Heidegger says in a world" (Levinas 2009, 337). Signifiers hermeneutically mean within interpretive frameworks that indeed define what the given [donnée] even is as well as what it means. "Like language, experience too no longer appears to be made up of isolated elements . . . and each signify by itself. They signify on the basis of the 'world' and of the position of the one that looks at them" (Levinas 1987, 78), Levinas clarifies in "Meaning and Sense," a published essay to emerge from these notes.

Yet Levinas's hermeneutics or frameworks of interpretation are not contained within the models of phenomenology, when these entail that understanding is how consciousness grasps experience as a unity of intentionality and intuition. Neither metaphor nor language nor understanding itself is for Levinas a moment of integrative intuition of which language, as a linear unfolding part by part in time, would inevitably be an inferior mode (Levinas 2009, 360). Signification is not "an ideal essence or a relation offered to intellectual intuition" (Levinas 2009, 370). Likewise metaphor, as both model and instance, is "not a modification of a signification which exists outside of language," and signification is "not born out of thought or simple correlatives of intuition. It refers already to significations" (Levinas 2009, 332). The mind no longer encloses or is enclosed in an "intentional structure of thought" (Levinas 2009, 337) against, as Levinas often repeats, Plato's reminiscence in which "the soul only receives what is already there, returning to itself" (Levinas 2009, 339). Levinas would break through this enclosure of self as an "interiority that is intuitive" (Levinas 2009, 379).

Levinas's distinctive contribution is to direct language theory beyond ontological, epistemological, or phenomenological analysis to ethics. In doing so, he challenges not only ontological structure, but its foundational presupposition of unity. As a figure of comparison, metaphor works in resemblance, which traditionally is seen to assume a shared essence common and prior to both of the compared terms. As Levinas writes: traditional metaphor projects "resemblance to resemblance as if entities existed prior to their comparison within an analogical structure pre-establishing likenesses: a resemblance of resemblance, . . . as if establishing coincidence between beings, objects and situations that reveal an analogy" (Levinas 2009, 326). Such analogical structure underwrites Platonist ontology itself: whether as in Republic X the world is a copy representing Ideas, or in Plotinus where world is emanated as shared Being through attenuating gradations of likeness. At the apex is unity: Plato's 
Ideas, as unchanging, must be non-multiple as well as immaterial: the multiplicity that the changingness of matter in time results in is precisely what defies its being what it is, true to itself as identical to itself. Plotinus's elevation of unity to the ultimate principle is plainly announced in calling it the One, beyond being since even being, unchanging as it essentially is, is in Plato's Ideas still multiple. Metaphor would be a glimpse through these multiple refractions to the unity thought to underlie them.

Levinas, however, moves meaning from such unitary Being to the time, change, materiality, and multiplicity which Platonism demoted as Becoming. He does so not firstly as an accusation of falsehood, what Nietzsche accuses as "the equation of what is dissimilar," thus erasing the "unique, absolutely individualized original experience" of particulars to "fit countless, more or less similar cases" which, however, "are never identical, and hence absolutely dissimilar" (Nietzsche 1989, 249). This erasure of unique particulars is to Levinas not only falsifying, but ethically violating. Unity is erasive. It must deny or destroy whatever cannot be incorporated into it. Thus, it generates as well as justifies violence. The appeal to unitary truths, Levinas writes in notes made as a prisoner of war of the Nazis, becomes a form of "colonization," of imposing one cultural mode onto another as if it were universal in ways that "serve exploitation and violence” (Levinas 2009, 381). Analogy consumes difference. The signifier is absorbed into the signified, its purpose of transmission fulfilled. Discourse itself can become the self reflecting on itself, the relation with the interlocutor one of "domination as the self retrieves its own memory" (Levinas 2009, 343). As Levinas writes elsewhere in his lecture notes: "The conception in which language merely transmits thought . . . is a philosophy of mastery, every human relation becomes inevitably a relation of power” (Levinas 2009, 80). Unity appropriates and effaces difference, an appropriation performed in a kind of conceptualization that subsumes difference in a drive to assimilation. Consolidation, Aufhebung, subsuming terms into each other while effacing their distinction, is a conceptual drive Levinas repeatedly and consistently sees to unfold throughout the traditions of Western ontology and truth. And he deeply suspects its ethical implications, as one of power and appropriation.

Unity of mind and being threatens violence against whatever lies outside it multiplicity, temporality, difference, the particular. Yet, abandoning all norms other than hermeneutics of cultural practices - Richard Rorty's position - may open another danger, that of sheer relativism. ${ }^{6}$ Levinas concurs with Nietzsche in

6 Richard Rorty, in urging not the "desire to know the truth" but "the desire to recontextualize," concedes "this is the desire to be as polymorphous in our adjustments as possible, to 
rejecting a Platonic definition of signification that is "separate from the world of becoming" (Levinas 2009, 381). But he also warns against the denial of all norms except those of cultural practices, norms that would make possible adjudicating among different cultural contexts and their hermeneutics of signification. In a concluding note to "La Métaphore," Levinas summarizes: "Metaphor in the sense of comparison as the structure of all cultural signification" results in the "purely relative." He then, however, asks: "Doesn't there exist signification in an other sense, one which is apprehensive of words and their cultural activities" (Levinas 2009, 346).

In seeking this "other" signification, Levinas proposes instead of unity an ontology and an ethic of multiplicity in which each signifier is other from any other. Signifiers would have a double relationality of both distinctiveness yet connection, connection in terms of the specific sign-chains in which they appear and are linked to each other. It would be a nominalism that would not rely on an ultimate ground that is, however, beyond reach, as in the medieval kind ${ }^{7}$ but rather a post-metaphysical nominalism that locates relationships within the changing world of particulars. ${ }^{8}$ Resemblances can of course still be drawn, but they would be relational, not essential, through what Rorty calls "recontexualization.” Yet unlike Rorty, Levinas introduces a transcendence that ruptures any context, that exceeds it, rupturing also any analogical reification within it.

Multiplicity here becomes a norm, rather than a failure of unity or sign of disorder, chaos, and meaninglessness, as is traditionally the case. The closed system of self-reflection and analogical ontology Levinas ruptures by a transcendence that will not be encompassed within it, interrupting totality and generating multiplicity but not as a fall: as a creative good. Transcendence acts, first, as an incursion within the signifying system. Each signifier transcends each other. In the unfolding of signification, then, there is an assertion of the distinctive integrity of each signifier, different from every other in which it is in relation. Difference thus becomes intrinsic to meaning, not as a dispersion that must be overcome but as a way signifiers relate to each other. Signifier terms are then no longer units "in a system of metaphoric relation which privileges the transfer of identical senses across a multiplicity they have in common" as background to be consolidated out of (Levinas 2009, 335).

recontexualize for the hell of it" (Rorty 1991, 110). He also states: "The pragmatist admits he has no ahistorical standpoint from which to endorse the habits of modern democracy he wishes to praise" except through our practice to "privilege our own group” (Rorty 1991, 29).

7 See Hans Blumenberg, The Legitimacy of the Modern Age (1983, 151 and following).

8 See for example Nelson Goodman and W. V. Quine, “Toward a Constructive Nominalism” (1947). 
"A literal meaning is inseparable from the figurative meaning," he writes more imagistically, "and neither vanishes nor is absorbed in the meaning that nourishes it, but the two meanings glimmer in the same dawn, both turned to the light” (Levinas 1987, 67). Indeed, this passage both describes and demonstrates self-reflexively Levinasian metaphor. A sign-chain of words involving light intercrosses with a sign-chain of words involving language, forming a new sign-chain of inter-relational terms which nevertheless retain their difference. New relationships emerge, not subordinating or incorporating the distinctive language webs out of which these new relationships are built. Thus signifiers are launched in new differential relationships, but not as subsumption, nor as dialectical or metaphoric synthesis.

Within the unfolding of signifiers, relationality is not the same as identity. Two identical terms would not be in relation; they would be identically the same. Relationality entails connection, but between distinct terms. There is a double relation of connection and distinction, proximity and distance, with difference taking precedence as the very condition of meaning. "Differences between signs concern thought before the identity of these signs" (Levinas 2009, 359). Levinas here accords with Saussure's differential relationality of signs, but rejects the notion of a "signified" to describe it, as Derrida does as well. As a differential relationality among signifiers, all language is figural. This relationality can be a comparison, as in a specific metaphor: such that two chains of signifiers crossover, bringing each chain into relation with the other through an intersecting term. Comparison would, however, also always retain difference. The transfer is never complete, with one term subsumed into the other.

"No given would bear identity forthwith," but would always appear within hermeneutic interpretation, just the way language means: as a "word that receives the gift of being understood from a context to which it refers" (Levinas 1987, 77). Levinas thus concurs with contemporary anti-Platonism, in language as in ontology and epistemology, refuting unitary Ideas as governing meaning. He, however, goes beyond other contemporary theorists, with the possible exception of Derrida, who in fact draws on Levinas, to address and outline an ethics of language precisely in theorizing it as inter-relational multiplicity.

This ethical turn is particularly marked and dramatized in a uniquely Levinasian shift in the models of signification. For in Levinas, discourse and its hermeneutics is not only a structure of relational signifiers as these reflect interpretive frameworks, but a relationship among the interpreters themselves. Beyond signifiers as structural units, Levinas insists on signifiers in a different sense: the persons who signify, who actively signal to each other 
and are thus inseparable from how, what, why, and for whom meanings occur. "Language is the only system of signs that does not turn back/refer only to the signified that it expresses but breaks the system to manifest the meaning that delivers the signs" (Levinas 2009, 369). Words are not "congealed into a literal meaning. In fact there would be no literal meaning." Words instead refer "laterally . . . to other words" as used in different contexts, for example in their etymology (Levinas 1987, 77). This is to move metaphor from a vertical structure to a horizontal one: "laterally" along and between sign chains or language networks. Levinas then further extends figural meanings beyond structure toward the "positions of the listeners and speakers." Signification occurs only among speakers/responders. "Language [even as] signifying thought is to someone, supposes the other . . . Language is not just instruction, but a call to the other" (Levinas 2009, 81). Speaker/responders, too, are signifiers as actors; signification via signifiers is their act. And as signifier-sayers, actors launching signs, they always exceed structure, stand outside its incorporation and systematization.

To insist on speaker/responders reaffirms the historicity and contingency of signification - "the contingency of their history" (Levinas 1987, 77). Yet, it also opens signification to the ethical dimension, which is Levinas's ultimate concern, a dimension that entails an absolute of ethical demand above all contingency. The differences which enter into a differential diachronic system, what Levinas quite technically calls "diacritics," in which "a sign points laterally to another sign” (Levinas 2009, 359; see also Levinas 2009, 378), also break out of the system. The interlocutors as signifiers in their address and response to each other - with each addresser a responder, each responder an addresser in the ongoing unfolding of discourse - also emerge relationally to each other. Yet they also exceed relation. Linked by the very language they address and respond to but are also absolutely and irrevocably separate from each other, they are other to each other beyond any signifiers they interchange, are ultimately unknown and unknowable to each other in any complete grasp or intuition of consciousness.

The relation among signifiers is not one of interiority through shared thought but "a relation with what is exterior" (Levinas 2009, 343), an "original relation with an exterior being," not as a "regrettable failure of intuition" but precisely as the "rightness of relation" (Levinas 2009, 371). It is this exteriority of multiple signifiers which do not erase, absorb, or incorporate each other but stand in relationships that both connect and distinguish that constitutes Levinasian ethics. Ethics is not recognition of self in self, empathy, identification, or universalization. Rather, it is the recognition and respect of the 
other as beyond grasp, claim, or full knowledge. But this is exactly to elevate multiplicity over unity: the multiplicity of signifiers "countless" beyond any possibility "to seize by inventory"; and the multiplicity of signifiers as speakers/ responders linked by language but across an absolute distance in which each is unique, each from the "position of the one that looks at them" (Levinas 1987, 77-78), a diversity of positions that cannot and should not be consolidated into one. Ethically, such diversity is experienced as it affirms uniqueness: each distinct signifier/person is unique, transforming or, rather, exposing the self-enclosed self as interlocutor speaker/responder: "the uniqueness of the I is the fact that no one can answer for me" (Levinas 1987, 97). "Multivocity, polyvalence, is the internal character of meaning." This extends beyond any "system" including metaphor as "this like that," which would assert fixed analogies. Rather, there would be genuine transformation and newness, newness possible only through openness to the truly different and other, "a germination which is meaning and not some kind of preference for the signified," where instead one object "responds to other objects by which it can be something other than what it is." In this, as in Levinas's ethics, radically and against all the philosophical centuries governed by analogical unity, "the multiplicity opened [would] in itself be intelligibility" (Levinas 2012, 321).

What then is metaphor? Rodolphe Calin has argued that metaphor in the Notes ultimately verges into what Levinas later calls trace - actually, Levinas himself introduces "trace” in his "Notes on Metaphor" (Levinas 2012, 328), asking this very question: "Does the excess of metaphor not come from the trace?" (Calin 2012, 136). Levinasian metaphor, like trace, is always in motion, never fixed essence, never final. Metaphor is an "excess of every going towards on High (Hauteur)" in "refusal of the end point" (Levinas 2012, 329). Metaphor in this sense does "come from the trace" which marks the passage of the other that remains ever beyond signifiers left in its wake, to which speakers and responders, signifiers in an active sense, speak and respond. The relation between speakers and responders then also exceeds itself. Each stands to the other outside their relationality. Levinas speaks of movement as against static correspondence, a "movement towards the infinite" (Levinas 2012, 325) that breaks through all closure and correlation: "There is a movement in language toward the infinite and there is no language without this movement. And this movement comes from the other insofar as language is response to another and excess of that which is said" (Levinas 2012, 328).

Metaphor, then, has a double status in Levinas. On one hand it is a term for the specific figures of comparison, not, however, as referring to a common essence but as linking together different sign-chains through terms that crossover between them: that is, establishing new links which continue to shift among 
further links as well as further differences and distinctions. On the other, metaphor is a term for all figuration, much as it is in Nietzsche's "Truth and Lying," where all language is seen to be metaphorical, that is, as figural whose meaning derives in networks of signifiers.

Levinas does not attempt to deny the possibility of analogy. But he rejects its foundational status, insisting that this "call of likeness to likeness" cannot exhaust metaphor's "role" (Levinas 2009, 326). Signification entails difference, but it also requires connection, which can include resemblance. Thus it is not accurate to say that Levinasian metaphor must "transcend all resemblance," as if to be "no longer situated in words, to divest of all reference," leaving only the "invocation of other that precedes all exchange of verbal signs" (Calin 2012, 132-134). The Height which exceeds metaphor does not refute it, leaving words behind into a higher silence as a "silent word" [parole silencieuse] (Calin 2012, 137); a word without what is Said [la parole sans Dit] (Faessler 2012, 152), a "speaking silence" [silencieusement parlante] (Guibal 2012, 171). There is a danger here to re-ontologize the beyond as if it were another higher state, displacing and demoting immanent experience and language. This would be to return to a two-world dualism not only ontologically but linguistically, where, as in traditions of negative theology, nothingness becomes a term for the higher world beyond immanence and beyond language, traditionally represented by silence. ${ }^{9}$

But Levinas protests the "mistrust of language" that is intrinsic to the Platonic tradition, its "exaltation of silence" and "distrust of language," where silence functions as a foundational trope for Being as a higher ontology (Levinas 2012, 132, 134). Levinas does insist that the ultimate other is beyond language as it is beyond being, but this is not to devalue language. It is to define its proper domain and role. Levinas elevates language as the arena of human interaction and ethics. "The world is significant in language" (Levinas 2009, 334), Levinas writes. Significance includes both signifiers in the sense of what is "Said," as Levinas later calls designation, that is, cognitive communication. It also intends signifiers as participants who address and respond, what Levinas later calls "Saying," which in Levinas is prior to, although it does not negate what is Said. "The signification of the interlocutor as interlocutor is not a signification like one that translates words ... that constitute the world"; it is first address and response to the other: "the other belongs to the order of the world through the role it plays there ... in the discourse in which I respond to the mundane signification" (Levinas 2009, 342). Language returns to "thought" but also consists in the

9 See Shira Wolosky, “Two Types of Negative Theology” (2017). 
“aim of the one to whom language addresses itself” (Levinas 2012, 326). The challenge is "at the same time to signify and not be enveloped in intellection" (Levinas 2009, 342), to affirm the "simultaneity of this designation and this transcendence itself” (Levinas 2012, 323).

Language thereby becomes both conduct and model to signification including signifier elements and signifier-sayer actors. Each opens another dimension, "a miraculous surplus" (Levinas 2009, 325). Surplus then reaches beyond signification, a "surplus that appears in the less" (Levinas 2009, 341). In transmitting "the call of the other," the sign not only "signifies significations, but resonates in language through which the Other presents as Other" (Levinas 2009, 368). To present as Other is an oxymoron: the other is what cannot be presented or present. It breaks into what is present, preventing determinate closure into system, including between speaker/responders. The other transcends whatever is experienced, as a break that disrupts and disorients any totalization and fixation, any unification of meaning. In terms of language Levinas comes to call this the "Unsaid," dedire as an absolute interruption of both Said and Saying, in which "the Infinite shuts itself up in a word and becomes a being but already undoes its dwelling and unsays itself without vanishing into nothingness" (Levinas 1998b, 145).

Levinas, in a break with Platonist tradition, rejects not only a two-world ontology, but a two-world language dualism. There is absolute distinction, that between the human world and transcendence. Although transcendence incurs into this world, breaking the grip of phenomenological consciousness as possessing others, this world cannot be transcended into another one. That is what transcendence means: the impossibility of transcending this world, and the error of trying to. "The beyond is not a simple background [as in Heidegger] . . . is not "another world" behind the world [as Nietzsche accuses Plato]; the beyond is precisely beyond the world: beyond every disclosure" (Levinas 1987, 102). Levinas speaks of metaphor as "movement to the beyond" (vers l'au dela): that is, movement to but not into. The beyond remains beyond, so that metaphor's movement is not "lost in the thought which absorbs in resemblance as in a static essence" (Levinas 2012, 325), "without stopping in a fixed correspondence which, instead of piercing into a higher signification would entrap in the closed world fixated in objects" (Levinas 2009, 340-341). Yet this world remains the arena for language. Metaphor at once exceeds a determinate given, yet is a way to affirm meaning within the "sensible and concrete significations" that "exceeds experience, remaining part of what it transfigures" (Levinas 2009, 326).

Metaphor, then, is redefined in Levinas in terms of a general theory of language as differential interrelationship of signifiers of which comparison is one 
sort, always, however, stretched across differentiation that is never fully overcome. Yet Levinas also emphasizes rupture that breaks even relational differentials, that exceeds all structure and system, all comprehension and grasp. This is his ethical check: putting beings altogether outside and beyond each other, as an ultimate respect of untouchable mystery, what he calls enigma. Enigma, again, is not then hypostasized into an alternative state beyond language as silence. Yet silence does penetrate language as marking its boundaries and resisting efforts to uphold each particular, each signifier. Although there is rupture, this mystery also institutes order, norms - the norm of preserving and respecting distinct particulars as valuable and never to be incorporated. It is enigma that sustains exteriority as against identification, but to generate the movements of meaning, not negate them. Levinas, interestingly, speaks of both disorientation and orientation: of the disorientation in rupturing closed and fixed systems; but as opening towards another "orientation," a "movement towards on high" which he also calls "God" (Levinas 2012, 322). Transcendence disorients, breaking into closed system; but it also reorients, through respect of difference in multiplicity that must be embraced and affirmed against the violence of unity. The claim to a direct or privileged contact with the world of Ideas is possible which, claiming "the emancipation of minds" can be used as "a pretext for exploitation and violence" (Levinas 1987, 101). This is not to chastise the ego as autonomous consciousness, but to affirm that the self, when "it loses its sovereign self-coincidence," is "not reducible to a negative moment" but marks the discovery of an "orientation [to be] infinitely responsible" to the Other (Levinas 1987, 97).

This ongoing, open back-and-forth between connection and distinction, never resolved into a dialectic subsumption but rather driving forward in an infinite generation without resolution through and beyond metaphor, is not a failure of coherence but a production of value in life. Indeed, this is how signification unfolds: as relationalities among the particulars in the world, including a concrete "diacritics" of the body "which signifies," an "expression of the body signifying laterally from sign to sign" (Levinas 2009, 362, 378). Above all, meaning unfolds as relationship across difference between signifiers who address and respond to each other. It points to a "beyond which it announces but does not represent, [to] language as a passage to an altogether other alterity” (Levinas 2009, 337). Rather than appeal to a unifying universal, signification launches inter-relations between particulars, "the generation of a particular from a particular" (Levinas 2012, 321) which Levinas also calls "trope" (Levinas 2012, 321). In this sense the "meta" of metaphor is a speaking beyond itself. Ultimately it an address to an Other which is the core of 
Levinasean ethics of language. We look beyond the signification of the words toward the Other who addresses but is never encompassed by us. All language is then meta-phorical, pointing from signifier to signifier and ultimately to its sign-givers and receivers.

\section{Enigma}

Metaphor thus is redefined to affirm multiple inter-relationships without closure and pointing beyond analogy. Yet another term comes to be introduced to safeguard such incompletion and insist on unintegrated difference: enigma. Enigma denotes the rupture that opens all inter-relation to new, further, infinite, unfinished, and multiple significations.

Levinas's essay "Phenomenon and Enigma” associates enigma, like metaphor, with trace. Like trace, enigma is not "like signs which recapture the signified” (Levinas 1987, 65). Enigma's "signifyingness" is one that is "absent from the very terms in which it was signaled” (Levinas 1987, 71). Enigma underscores the non-analogical in signification, the rupture that at once secures signification and also breaks through it into the ungraspable.

Enigma contests the rule of traditional metaphor, and the hermeneutics and phenomenology it both implies and constructs. Levinas's formulations can be interestingly compared to Paul Ricoeur's, whose The Rule of Metaphor is a central text of metaphor theory. In it, analogical structures retain their commanding role, indeed rule, such that "the same operates in spite of the different" (Ricoeur 1987, Rule 196). Levinas, however, insists on difference as it withstands and disturbs the same. Interestingly, Ricoeur refers to "enigma" as precisely the "tension, contradiction, and controversion" of usages "to which the metaphorical meaning offers the solution" (Ricoeur 1987, Rule 194-195). What Ricoeur calls "enigma” is a site of inconsistencies "the reconciliation of which metaphor 'makes sense", (Ricoeur 1987, Rule 195). Resisting such reconciliation is precisely Levinas's project. Enigma does not "resemble terms of an already familiar order" (Levinas 1987, 62), an order which Levinas (like Ricoeur) identifies with phenomenology. Phenomena as apprehended in consciousness he describes as an appearing which "assembles" time and manifestation as contemporaneous, present within the "understanding of being" that has defined philosophy (Levinas 1987, 61, 63). But enigma ruptures such contemporaneity and correlation in ways that cannot be recovered or reconciled. As in its etymological sense of "riddle," enigma counters phenomenology as an "impossibility of manifesting" (Levinas 1987, 66, 62), a "transcendence which ventures beyond being” and "beyond thought” (Levinas 1987, 62). 
“Enigma and Phenomena” reiterates Levinas's critique or language theory in the Platonist tradition. There is no "signified" as a pre-given meaning that happens outside of discourse, which language would represent as secondary signifier. As Levinas puts it, "language does not come to double up phenomena" (Levinas 1987, 69). Phenomena do not "indicate an order of "things in themselves' of which [there] would be signs." There is no structure of "signifieds" prior to and independent of signifiers. There are no "signs which recapture the signified" (Levinas 1987, 65), no "conjuncture" or "simultaneity between the indicated and indicated terms" (Levinas 1987, 65).

Articulation is signification that emerges among signifiers interrelationally, without some prior signified they would express, indicate, or represent, what he calls a "chain of significations which constitute the world" (Levinas 1987, 62), a "rational enchainment of its significations" (Levinas 1987, 70). These signifiers do not represent an ontologically independent signified, but instead unfold meanings through lateral interrelation. The function of signifiers is not to offer representation and ultimately phenomenological comprehension and hermeneutic integration. Chains of signifiers, even as metaphors, never complete representation, never offer a "simultaneity of one single order," nor even a "meeting of two series of significations that each, with equal rights, lay claim to the same phenomenon" (Levinas 1987, 67-68). Even in the substance of a communication, Levinas's "Said," the chain does not signify a signified prior to it and is never fully constituted, but is always ongoing, open, open to rupture and to whatever exceeds its enclosure. "The enchainment of an account is exposed to interruption" (Levinas 1987, 69), writes Levinas. This is the interruption of enigma. It marks a discourse which does not fulfill "the structure of an intentional correlation" (Levinas 1987, 73), running counter to a "signifyingness . . . that awaits a concept capable of finding and grasping it" in a "sphere that is present" (Levinas 1987, 71).

Such interruption breaks through differentials within a diachronic system. It announces an absolute otherness which is never recuperated, which breaches all closures, "cutting the threads of the context" (Levinas 1987, 65). This first occurs in that every sign system is also enacted as address/response, with speakers/responders multiplying positions that open the senses of signs beyond any closed intention. This ultimate ungraspability breaks into not only sign-system but relation between interlocutors who remain other to each other, enigma to each other. Levinas refers to this as "withdrawal," foreseeing the Dedire, the Unsaying of Otherwise than Being, which he there associates with enigma as "unsaying in the ambiguity or the enigma of the transcendent, in which the breathless spirit retains a fading echo" (Levinas 1998b, 44). The infinite, exceeding all determination, is a "withdrawal like a farewell which is 
signified" not "to inundate it with light, but in being extinguished in the incognito" (Levinas 1987, 71-72). Enigma as trace does not "signify [] as a sign.” It is the very emptiness of an irrecuperable absence, . . the gaping open of emptiness that is not only the sign of an absence . . . but the very emptiness of a passage" (Levinas 1987, 65-66).

Enigma thus exceeds and disrupts the signified/signifier correlations of both classical sign-theory and theories of metaphorical resemblance. Enigma is ungraspable, both in terms of representation of what is "said" and the other which "Saying" addresses/responds to. As absent signified or signified absence enigma marks "the intervention of a meaning which disturbs phenomena but is quite ready to withdraw" as "footsteps that depart [as] transcendence itself, the proximity of the Other as Other" (Levinas 1987, 70).

Ricoeur directly contests Levinas's radical alterity. In Oneself as Another (1992), Ricoeur insists on an interchangeability or transfer between self and other. The "irreducible disturbance" Levinas insists on as unbridgeable by analogical relations that metaphor sustains (Levinas 1987, 63), Ricoeur sees as unraveling sense altogether. Of Levinas, Ricoeur writes: "to the extent that the other represents absolute exteriority with respect to an ego ('moi') defined by the condition of separation . . . The other absolves himself of any relation. This irrelation defines exteriority as such" (Ricoeur 1992, 188). Exteriority as denying analogical substances as in metaphor and intentional consciousness seems to Ricoeur to threaten "irrelation," the loss of relationship altogether. Ricoeur thus complains that Levinas, in his radical transcendence expressed as absence, void, and negation, allows “no middle ground, no 'between' secured to lessen the utter dissymmetry between the Same and the Other” (Ricoeur 1992, 338).

To mediate the opening of the Same to the Other and the interiorization of the voice of the other in the same, language must have its resources of communication, i.e., reciprocity. Doesn't dialogue require superposing relation on "absolute distance" so-called between the separate me and teaching other?

$\left(\right.$ Ricoeur 1992, 339) ${ }^{10}$

As Ricoeur writes in The Rule of Metaphor, loss of represented signified anchored in analogical ontology threatens loss of significance and discourse itself, a fall into relativism and willfulness: "When the reference to objects set

10 Here Ricoeur and Levinas echo and reenact an old theological dispute, that between Aquinas and Maimonides, where Maimonides insists on an absolute non-analogy between the divine and creation and Aquinas insists on the mediation of analogical via eminentiae where, as Faessler notes, scholastic ontology affirms "the path of analogy where formal beings resemble supra-eminent divine Being” (Faessler 2012, 157). 
over against a judging subject is suspended, is not the very structure of utterance shaken?” (Ricoeur 1987, Rule 306).

But Levinas, while refusing Ricoeur's "interiorization of the voice of the other in the same" still does not defeat relationship, such that enigmatic trace would be only a "sign of a remoteness" (Levinas 1987, 65). Instead, he redefines relationship as across absolute distinction - distance and relation, what he calls "unrelating relation" (Levinas 1969, 295). He thus rejects the submergence of transcendence into a "totality which gives it meaning." Yet he does not concede that "to refuse this primordial order of contemporaneousness" means "ceasing to signify" (Levinas 1987, 63). What emerges is a different mode of signification from that of representation, which Levinas sees ultimately as a mode of narcissism. Levinas insists: "the Other cannot also not appear without renouncing his radical alterity, without entering into an order" (Levinas 1987, 64). Neither through metaphor nor symbol, the other is not shown in any phenomenological sense: "The infinite is an inassimilable alterity, a difference and absolute past respect to everything that is shown, signaled, symbolized, announced, remembered, and thereby 'contemporized' with him who understands" (Levinas 1987, 71).

But how then is positive relation, signification itself possible? Levinas's radical shift from ontology to ethics moves from representation to response as address/response to otherness. The relation to the other is not one of cognition or correlation or participation but rather of ethical regard: the approach to the Other as "beyond cognition and disclosure in enigma is ethics" (Levinas 1987, 73). "Enigma is ethics," as response that "break[s] the undephasable simultaneity" of representation (Levinas 1987, 63). Enigma as unsaying initiates an "extravagant response," which "think[s] more than one thinks, to think of what withdraws from thought" (Levinas 1987, 72). Yet this is also a "summons to moral responsibility" precisely in failing to claim to encompass, grasp, or finalize analogy (Levinas 1987, 72). As “summons," enigma affirms relation; but as unsaying it "withdraws," thus sustaining difference, the transcendence which safeguards the other, so that "morality is the enigma's way" (Levinas 1987, 72).

Levinas's view of metaphor would thus be one in which, as in his ethics, the alterity of the other is never absorbed into the artwork as a self-sufficient representation. It would be to enact a "relationship with the infinite" that does not have the structure of "correlation," that breaks the "simultaneity of representation," pursuing instead an "approach" that "signifies itself without revealing itself," "that retracts, withdraws, fails to be grasped” (Levinas 1987, 72-73). Enigma projects poetry not as representation nor as formal closure, 
but instead as exposing and resisting any total account or comprehension. Enigma, like unsaying, ruptures the language event, and so safeguards its generativity. Insisting on areas that signifiers and those who signify them, the Said and Saying, cannot reach, that transcend human linguistic grasp and must not be claimed, it opens aesthetics towards ethics.

\section{The Enigmatics of Marianne Moore}

Levinas's enigma opens a different avenue into the analysis and experience of poetic texts than traditional metaphorics does. It is especially suitable to certain kinds of modernist and post-modernist writing, which also grapple with post-metaphysical challenges to what had been for centuries the governing rule of analogical being. As an example I will take Marianne Moore.

Moore's poetry is regularly described as ethical. Her ethical commitments can be felt through many of her characteristic poetic techniques: its practices of quiet attention to features otherwise often overlooked, such as her almost inaudible yet exquisite half- rhymes which respect even insignificant syllables and parts of speech, and her careful counting of inaudible metrical syllabic patterns, enact as form a respectful and grateful attention and appreciation of language and world. Her figure of the poet similarly proposes a self in abeyance, undramatized, whose craft configures myriad, often diminutive, details, as opposed to sublime visions. Often she echoes others' voices in direct and indirect citations, drawing on traditions that she also recasts. What emerges is an aesthetic of trace, of concealment/revelation, as an affirmation of mystery: a sense of further dimension, never fully commanded or completed, where the spiritual beckons to further meanings, as does the poetic. There is never totalized expression, but rather a procedure that recalls Levinasian notions of interruption and breach, through linguistic positing and retraction as enigma. I take Moore's "By Disposition of Angels” as an example:

\footnotetext{
Messengers much like ourselves? Explain it.

Steadfastness the darkness makes explicit?

Something heard most clearly when not near it?

Above particularities,

these unparticularities praise cannot violate.

One has seen in such steadiness never deflected, how by darkness a star is perfected.
} 


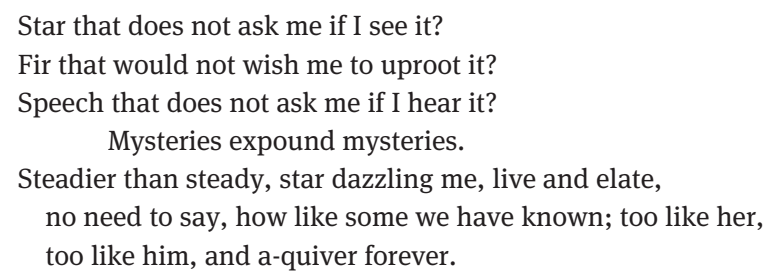

(Moore 1994, 142)

This poem's careful craft is characteristically concealed, in oblique but pleasurably traceable formal disciplines. The rhyme scheme is irregular and partial: rhyming "it," "explicit," "near it," and "violate." "Particularities," in the fourth line of the first stanza, matches "Mysteries" (itself interesting), in the fourth line of the second stanza, as do the fifth lines of each stanza ("violate"/"elate"). Each stanza concludes with its own couplet ("deflected"/"perfected"; "her"/ "forever"). Syllable counts match in Moore's own odd quantitative way: in each stanza, lines 1, 2, 3, and 7 have ten syllables, line 4 has eight syllables, and lines 5 and 6 have fourteen syllables.

As to text, Moore begins with the Hebrew meaning of angel as messenger, not only as sent from God to address humans, but as a messenger in an ordinary sense. In this sense, angels are like us. Yet the first line sets out to investigate the word "like." "Explain it" is an invitation, or imperative, to hermeneutics - which if undertaken through fusions of horizons, and mediating unities between distinctives - Moore's "particularities" - is something Levinas suspects. Moore's "like" is equally cautious and self-effacing, marking less a relation of similarity and continuity then of difference and distance. What seems to need explaining is just how "Messengers" are "much like ourselves," given the ineffaceable difference between the two. "Steadfastness," which demarks loyalty but not identity, is made in an oxymoron "explicit" by "darkness." "Explicit" here plays against its rhyming "Explain it," both as question and as suggesting emergence rather than explication, and in any case via "darkness"; as continued mystery and not complete illumination. Hearing is similarly most clear "when not near it," across distance.

This "not near" in fact inaugurates what will be in the text a pattern of negatives, always enacting distances and hence performing integrities of difference. Thus, if the messengers are "Above particularities," they gain specification only by retraction as "unparticularities," not by leaping into universals. Removed from language - "praise cannot violate" them - words move into distance as remote, unlike; yet always retaining their value, never negated into silence. "Darkness," here repeated, becomes a scene of emergence, while perfection itself 
is made ongoing and temporal in tense, as process: "how by darkness a star is perfected." To be remote and not completely penetrable is part of the star's radiance.

The second stanza pursues this remoteness. It affirms three expressions of "not" ("would not" and twice "does not"). One pertains to the world, as a limit on our power over it: "Fir that would not wish me to uproot it?" denies us the right to uproot what is given in the world. Here our inevitable personifying is interrupted by negation: the tree "would not wish" retracts, in its selfexposure and denial, the personification it offers. Immediately before and after that line, the stanza twice bids to "not ask me," first of the star, then of speech itself. This is not, however, to deny address, but to establish it: the speaker sees and hears without first asking. The initiative comes from outside. It can be thought of as an interlocutionary although not symmetrical "Saying," in Levinas's terms, from other to self. What follows is a series of phrases that do not claim likeness. The poem in fact offers little by way of analogy. "Steadier than steady" intensifies but does not compare. What there is "no need to say" is exactly "how like some we have known." Instead of knowledge in or as likeness, there is mystery, also intensified in grammatical iteration. If "Mysteries expound mysteries" this leads not to clarification, but rather opens toward further depths that are never fully fathomed. Light itself yields a darkness that, however, also elates, uplifts. "[S]tar dazzling me" recalls a persistent mystical trope of revelation, but which here is not unitive, but keeps the self in an accusative and distinct state. "[T]oo like her, / too like him" extends to both genders but also paradoxically confutes them: how can it be like both in their difference? Finally, "a-quiver forever" again verges on oxymoron, joining temporal quivering with eternity - or is it infinity in a Levinasian untotalized sense?

The title of this text - "By Disposition of Angels" - uncannily recalls Levinas's problematic of deposing, which he calls an ethical "positing of the self as a deposing of the ego" (Levinas 1998b, 58) although in the name of a "uniqueness" of each responsive, responsible self. Levinas asks: "is not the very opening of the dialogue already a way for the I to . . . deliver itself, a way for the I to place itself at the disposition of the You?" (Levinas 1998a, 150). In the poem, "disposition" points towards a paradoxical placing that also displaces grants and disposes. Moore's title points to but keeps apart. The angels as messengers remain between poles, displaced but at the disposal of those before whom they appear and disappear, like and unlike, never fully grasped within the integrations of analogy. 


\section{Bibliography}

Blumenberg, Hans. The Legitimacy of the Modern Age. Cambridge: MIT Press, 1983.

Calin, Rodolphe. "La Metaphore absolue. Un faux depart vers l'autrement qu'etre." Levinas: au-delà du visible. Études sur les inédits de Levinas des Carnets de captivité à Totalité et Infini. Eds. Emmanuel Housset and Rodolphe Calin. Cahiers de philosophie de l'Université de Caen 49 (August 2012): 125-141.

Clark, Maudemarie. Nietzsche on Truth and Philosophy. New York: Cambridge University Press, 1990.

Cohen, Richard. “Levinas on Art and Aestheticism: Getting 'Reality and Its Shadow’ Right.” Levinas Studies 11 (2016): 149-194.

Cools, Arthur. "Trace and Resemblance in the Face of the Other: On the Problem of Metaphor in Levinas's Philosophy." Metaphors in Modern and Contemporary Philosophy. Eds. Arthur Cools, Walter Van Herck, and Koenraad Verrycke. Antwerp: University Press, 2013. 243-258.

Derrida, Jacques, Positions. Trans. Alan Bass. Chicago: University of Chicago Press, 1972.

Derrida, Jacques. Of Grammatology. Trans. Gayatri Spivak. Baltimore: The Johns Hopkins University Press, 1974.

Derrida, Jacques. "White Mythology: Metaphor in the Text of Philosophy." Margins of Philosophy. Trans. Alan Bass. Chicago: University of Chicago Press, 1982. 207-272.

Faessler, Marc. "Metaphor et Hauteur." Lévinas: au-delà du visible. Études sur les inédits de Levinas des Carnets de captivité à Totalité et Infini. Eds. Emmanuel Housset and Rodolphe Calin. Cahiers de philosophie de l'Université de Caen 49 (August 2012): 143-160.

Goodman, Nelson, and W. V. Quine. "Toward a Constructive Nominalism.” The Journal of Symbolic Logic 12.4 (December 1947): 105-122.

Guibal, Francis. "En chemin vers le sens du langage." Lévinas: au-delà du visible. Études sur les inédits de Levinas des Carnets de captivité à Totalité et Infini. Eds. Emmanuel Housset and Rodolphe Calin. Cahiers de philosophie de l'Université de Caen 49 (August 2012): 161-178.

Levinas, Emmanuel. Totality and Infinity. Trans. Alphonso Lingis. Pittsburgh: Duquesne University Press, 1969.

Levinas, Emmanuel. Collected Philosophical Papers. Trans. Alphonso Lingis. Dordrecht: Martinus Nijhoff Publishers, 1987.

Levinas, Emmanuel. Of God Who Comes to Mind. Trans. Bettina Bergo. Stanford: Stanford University Press, 1998a.

Levinas, Emmanuel. Otherwise than Being. Trans. Alphonso Lingis. Pittsburgh: Duquesne University Press, 1998b.

Levinas, Emmanuel. Parole et Silence, Oeuvres 2. Eds. Rodolphe Calin and Catherine Chalier. Paris: Grasset, 2009.

Levinas, Emmanuel. Notes on Metaphor. Trans. Andrew Haas. International Journal of Philosophical Studies 20: 3 (2012): 331-347.

Moore, Marianne. Complete Poems. New York: Penguin Books, 1994.

Nietzsche, Friedrich. Philosophy in the Tragic Age of the Greeks. Trans. Marianne Cowan. Washington, D.C.: Regnery Publishing, 1962. 
Nietzsche, Friedrich “The Dawn," The Portable Nietzsche. Trans. Walter Kaufmann. New York: The Viking Press, 1968. 73-75.

Nietzsche, Friedrich. Friedrich Nietzsche on Rhetoric and Language. Eds. Sander L. Gilman, Carole Blair, and David J. Parent. New York: Oxford University Press, 1989.

Ricoeur, Paul. The Rule of Metaphor: Multi-Disciplinary Studies of the Creation of Meaning in Language. Trans. Robert Czerny with Kathleen McLaughlin and John Costello. New York: Routledge, 1987.

Ricoeur, Paul. Oneself as Another. Trans. Kathleen Blamey. Chicago: University of Chicago Press, 1992.

Rorty, Richard. Objectivity, Relativism, and Truth: Philosophical Papers, Vol. 1. New York: Cambridge University Press, 1991.

Wolosky, Shira. "Two Types of Negative Theology." Negative Theology as Jewish Modernity. Ed. Michael Fagenblat. Bloomington: Indiana University Press, 2017. 161-179.

Wolosky, Shira. "Religion and Literature." Palgrave Macmillan Handbook on Philosophy and Religion. Ed. Barry Stocker, New York: Palgrave Macmillan, 2018. 645-664. 
